・论坛・ 中国国家植物园专题

\title{
国家植物园设立为何首选北京?
}

\author{
马金双 $0^{*}$
}

北京市植物园, 北京 100093

马金双 (2022) 国家植物园设立为何首选北京? 生物多样性, 30, 22013. doi: 10.17520/biods.2022013.

Ma JS (2022) Why should Beijing be the first choice for the establishment of the National Botanical Garden? Biodiversity Science, 30, 22013. doi: 10.17520/biods.2022013.

\section{Why should Beijing be the first choice for the establishment of the National Botanical Garden?}

Jinshuang Ma ${ }^{(\mathbb{D} *}$

Beijing Botanical Garden, Beijing 100093

2021年12月28日国务院批复在北京设立国家 植物园(国函〔2021〕136号), 由国家林草局、住房 城乡建设部、中国科学院、北京市人民政府合作共 建, 依托中国科学院植物研究所和北京市植物园构 建南、北两个园区统一规划、统一建设、统一挂牌、 统一标准、可持续发展的新格局, 同时要求相关部 门统筹规划、合理布局, 稳步推进全国国家植物园 体系建设。那么国家植物园为何首选在北京?

首先, 国家植物园是国家层面从事植物收集与 保护、科学研究、科普教育、园林园艺和文化休闲 于一体的综合性国家级机构, 也具有国家行业领域 内植物园(含树木园)的标准设计、技术规范、体系 监制和考核评价的权威管理与监督职能。国家植物 园是国家经济、科技、文化、卫生、环境、社会可 持续发展水平的标志性象征, 首选在北京无疑具有 统筹、管理和监督等多方面的优势。北京是中国的 首都, 更是中国的政治与文化中心, 在北京首先设 立国家植物园具有得天独厚的优势以及其他地方 无法替代的作用。世界上很多著名的国家级植物园 也是设在首都, 如澳大利亚的国家植物园位于堪培 拉、爱尔兰的国家植物园位于都柏林、美国的国家
植物园位于华盛顿、西班牙的皇家植物园位于马德 里、英国的皇家植物园邱园位于伦敦等。国家植物 园在北京设立仅仅是国家植物园体系建设的开始, 由此将推动全国具有不同代表性的其他地区的国 家植物园设立。国家植物园作为国家的象征与名片, 首选在北京设立具有明显的代表性和示范性, 可谓 名正言顺、众望所归。

其次, 植物园是公益性事业单位, 需要大量的 资金投入，经济上的考虑必不可少。设立国家植物 园必须考虑国情, 特别是中国还是一个发展中国家, 设立国家植物园既要考虑紧张的土地资源, 又要综 合考虑人力、财力和物力。位于北京的中国科学院 植物研究所及其植物园和北京市植物园不仅历史 悠久、积累雄厚, 而且优势明显且资源互补。特别 是成立于1928年的中国科学院植物研究所在植物 学领域的研究国内首屈一指, 人才雄厚、队伍强大, 基本设施与科研平台完善, 而成立于1956年的北京 市植物园在植物收集与保护、园艺展示、科学普及 等领域优势突出, 且具有从平原到山区的自然地理 优势; 南北两个园区统一规划、统一建设、统一挂牌、 统一标准, 建立可持续发展的新格局, 不仅强强联

收稿日期: 2022-01-10; 接受日期: 2022-01-11

* 通讯作者 Author for correspondence. E-mail: jinshuangma@gmail.com; majinshuang@beijingbg.com 
合，而且优势互补。

第三, 中国幅员辽阔, 疆域从北到南、从东到 西, 各有特色, 且植物种类繁多; 不论首选南方还 是北方, 内地还是沿海, 都无法兼顾不同的地域特 征或者资源特色。然而, 中国毕竟是一个北温带国 家, 温带面积占国土面积的大半 (秦岭至淮河为公 认的南北分界带), 温带气候性质明显, 国家植物园 选择位于温带的北京, 具有鲜明的代表性。另一方 面, 植物园保存的不仅仅是露地植物, 还有很多温 室植物。温带的北京干旱少雨并不意味着不能研究 或者保存植物。世界著名的邱园地理位置达北纬 $50^{\circ}$ 以上, 而北京仅北纬 $40^{\circ}$; 以色列以干旱著名, 其农 业上的奇迹举世闻名。此外, 国家植物园面积上固 然要有一定的规模, 但并不是越大越好。目前两个 植物园开放总面积达304 ha (其中南园约73 ha, 北 园约231 ha), 按照规划, 北园北侧山林纳入国家植 物园范围, 总面积近600 ha。目前南北两家植物园 的露地活植物以及温室的栽培植物总计已达 274 科 2,200属近17,800类群(APG IV系统, 包括野生物种 和栽培品种, 除双方共有的重复类群), 这样的数据 无疑显示了其已有的良好基础及绝对优势。

第四, 南北两个植物园历史上就是一家。1954 年, 中国科学院植物研究所的 10 位年轻工作人员给 毛主席写信, 申请永久的植物园地址, 并建立像苏 联科学院那样的总植物园; 1954年12月22日, 北京 市政府正式致函中国科学院: 同意在卧佛寺附近划 定566 ha，在当时的香卧公路以南划定96.6 ha, 作 为北京植物园永久园址的规划范围。1956年5月18 日国务院正式批复设立北京植物园, 同时划拨专款 作为第一期建园经费; 同年10月, 中国科学院与北 京市委签订了合作建设合约; 1957年中国科学院和
北京市成立北京植物园规划设计委员会, 启动建园 工作。尽管前者隶属于中国科学院, 后者隶属于北 京市, 但两园仅一路之隔。南北两园历经几代人近 七十年的艰苦努力, 在植物收集与展示、科学研究、 园区建设等方面取得了卓越成就。在南北园现有基 础上建设国家植物园, 既可减少建设过程中的资源 重复浪费, 又可节省人力、财力和物力, 可谓一举 多得。

植物是人类赖以生存的基础, 人类的衣食住行 离不开植物, 而植物园是人类认识植物、改造植物 并利用植物的关键场所。植物园有史以来的宗旨都 是收集、研究、展示、利用。随着人类活动的影响 加剧, 一些珍稀濒危植物受到威胁甚至灭绝, 再加 上外来入侵植物的出现，不仅造成巨大经济损失， 而且破坏人类赖以生存的生态系统。保护植物及其 多样性便成为当今植物园的重任, 这在21世纪的今 天更显得格外突出。保护不只是从野外挖回来栽培, 更重要的是要研究其濒危机制, 解析原因, 进而使 之种群延续、资源永存, 同时还要保护其赖以生存 的环境, 使其生物多样性和生态系统健康并持续发 展, 更好地为人类服务。因此, 植物的就地保护和 迁地保护便成为当今保护植物多样性不可或缺的 两个部分; 国家公园等自然保护地主要针对前者, 而国家植物园则侧重后者, 两者相辅相成, 共同承 担保护的使命, 使得人类不但有充足的赖以生存的 基础, 还要有美丽、舒适、优雅、宜居的生存环境。

\section{ORCID}

马金双 (1D) https://orcid.org/0000-0001-5899-4640

(责任编辑: 周玉荣) 